\title{
DEVELOPING INSTRUCTIONAL DESIGN IN DISTANCE TRAINING AT BALAI DIKLAT KEAGAMAAN JAKARTA
}

\section{PENGEMBANGAN DESAIN INSTRUKSIONAL PELATIHAN JARAK JAUH ONLINE DI BALAI DIKLAT KEAGAMAAN JAKARTA}

\author{
Marina Setiawati \\ Balai Pendidikan dan Pelatihan Keagamaan Jakarta \\ Jl. Rawa Kuning Cakung Jakarta Timur \\ e-mail: setiawatimarina@gmail.com
}

\begin{abstract}
The purpose of developing instructional is to contribute to the concept of thought in consulting at BDK Jakarta, particularty in developing instructional design to online training. Secondly, is to foster the creativity of Widyaiswara (Instructors), so that they can contribute to online training development. The consulting concept is expected to mediate instructors develop the online training designs in the future. Consultancy is initiated with situation analysis, and data collection stage is taken before designing and planning a consulting program. Situation analysis aims to collect information including types and forms of activities, parties or the public involved, actions and strategies to be taken, tactics, and the budget needed to implement the program. The result shows the consultation as an online training transformed into a new type of instructional design. This new type of instructional design has been validated by experts and peers through discussion.
\end{abstract}

Keywords: instructional design, online training, standardization

\section{PENDAHULUAN}

Pendidikan dan pelatihan (diklat) merupakan salah satu faktor penting dalam pengembangan sumber daya manusia. Diklat yang dilaksanakan untuk meningkatkan kompetensi pegawai merupakan bagian dari tugas pemerintah, termasuk di lingkungan Kementerian Agama. Dalam rangka melaksanakan Peraturan Menteri Agama Nomor 4 Tahun 2012 khususnya yang terkait dengan penghapusan dikotomi layanan kediklatan (PNS dan Non PNS), Balai Diklat Keagamaan (BDK) Jakarta memiliki wilayah kerja Kementerian Agama Pusat, Kantor Wilayah (Kanwil) Provinsi DKI Jakarta, Provinsi Banten dan Kalimantan Barat (Peraturan Menteri Agama Republik Indonesia Nomor 4 Tahun 2012 tentang Penyelenggaraan Pendidikan dan Pelatihan Teknis di Lingkungan Kementerian Agama Pasal 2, h. 4). Diversifikasi penyelenggaraan diklat melalui Diklat Di tempat Kerja ( DDTK) dan Diklat Jarak Jauh (DJJ). DJJ yang dilakukan secara online diharapkan dapat mengurangi keterbatasan biaya, ruangan, dan waktu dengan terbatasnya SDM. Penetapan materi diklat dilandasi hasil Training Need Analysis (TNA). Pada Tabel 1 adalah jenis-jenis diklat yang dikembangkan pada DJJ online di BDK Jakarta sejak tahun 2012. 
Tabel 1. Jumlah diklat yang dikembangkan pada DJJ di BDK Jakarta

\begin{tabular}{cll}
\hline Tahun & \multicolumn{1}{c}{ Jenis diklat yang dikembangkan pada DJJ di BDK Jakarta } \\
\hline $2012-2013$ & 1. & Diklat Penilaian Hasil Belajar bagi guru \\
& 2. & Diklat Penyusunan Rencana Pelaksanaan Pembelajaran bagi guru \\
& 3. & Diklat Model-Model Pembelajaran bagi guru \\
& 4. & Diklat Teknik Penghitungan Angka Kredit Penyuluh untuk keagamaan bagi \\
& guru \\
& 5. & Diklat Angka Kredit bagi Penyuluh \\
\hline $2015-2016$ & 6. & Diklat Penelitian Tindakan Kelas \\
& 7. & Diklat KTI bagi Penyuluh dan Penghulu \\
\hline 2017 & 8. & Diklat Operasional Komputer bagi pegawai \\
\hline 2018 & 9. & Diklat Penyusunan SKP \\
\hline 2019 & 10. Diklat Mutimedia bagi guru & \\
& 11. Diklat Penilaian Kinerja Guru (PKG) dan Pengembangan Keprofesian \\
& Berkelanjutan (PKB) & \\
\hline
\end{tabular}

Sumber: Dokumen Laporan BDK Jakarta

Jenis-jenis Diklat Jarak Jauh Online di BDK Jakarta harus terus dikembangkan mengingat di era 4.0 ini diklat dengan pola e-learning harus senantiasa semakin dikembangkan (Nugraha, 2020; Restendi, Nugraha, Triyanto, 2020), hal ini tampak dari meningkatnya antusias peserta khususnya guru-guru setiap tahunnya karena diklat online ini sangat membantu guru-guru dalam memenuhi salah satu komponen dalam angka kredit guru yaitu Pengembangan Diri yang merupakan syarat pada kenaikan pangkat guru, sebagaimana yang dikemukakan dalam artikel Rachmawati (Rachmawati, 2019). Guru-guru di wilayah binaan BDK Jakarta aktif mengikuti DJJ online setiap tahun, sehingga beberapa guru sudah mengikuti semua diklat yang dikembangkan di BDK Jakarta. Untuk itu BDK Jakarta harus proaktif dengan mengembangkan jenis-jenis diklat online baru. Kevariatifan dalam pelaksanaan Diklat ini telah dikemukakan pula dalam penelitian Helmansyah (Helmansyah, Prawira, \& Nugraha, 2021).

Selain masalah keperluan guru yang membutuhkan legalitas pengembangan dirinya, yang diindikasikan dengan telah mengikuti kediklatan, namun para guru karena keterbatasan waktu dan jarak, mengikuti diklat secara online. Pada saat ini ditambah dengan problematika pendidikan di Indonesia saat ini muncul akibat wabah penyakit pandemi corona (Covid-19). Pada sektor pendidikan terdampak akibat penyebaran virus corona yang terjadi sangat cepat ke berbagai negara di dunia. Akibat virus corona, untuk pencegahan penyebaran covid Pemerintah salah satu program pemerintah adalah dengan pembatasan sosial. Banyak kegiatan yang harus terhenti dan dialihkan dengan cara WFH (Work From Home). Begitu juga dengan kegiatan di bidang pendidikan. sehingga kegiatan pembelajaran secara tatap muka tidak bisa dilaksanakan. Beberapa artikel yang berkenaan dengan pembelajaran jarak jauh (online) antara lain telah dikemukakan oleh (Prawira \& Nugraha, 2021), (Helmansyah et al., 2021), (Kurnia \& Prawira, 2020). Dunia pendidikan pada masa pandemi covid-19 ini dituntut untuk dapat melaksanakan proses pembelajaran secara daring. Oleh karena itu, untuk pemenuhan kebutuhan stakeholder di BDK Jakarta yang sudah tiap tahun menyelenggarakan Diklat online ,dituntut untuk mengembangkan desain pembelajaran untuk jenis diklat online yang lebih beragam sebagaimana dikemukakan Kurnia bahwa perlunya pemenuhan kegiatan pembelajran online (Kurnia \& Prawira, 2020).

Sistem pembelajaran yang efektif, efisien, dan menarik perlu didesain, kegiatan ini sering disebut dengan istilah Instructional Development. Beberapa istilah digunakan dalam konteks ini seperti instructional system development (ISD), instructional development, dan instructional design. Asociation for Education and Communication Technology (AECT) memakai definisi Instructional Development yang diusulkan oleh Seels dan Richey yaitu "an organized procedures that include the steps of analyzing, developing, implementing, and evaluating instruction" ). Definisi ini menyatakan bahwa prosedur tertata yang meliputi langkah penelaahan, pengembangan, penerapan dan evaluasi dari sebuah pembelajaran. Kesamaan definisi pengembangan instruksional dengan desain instruksional juga dikemukakan oleh Suparman dalam Nasrudin bahwa pengembangan instruksional atau desain instruksional adalah suatu proses sistematis dalam mencapai tujuan instruksional secara efektif dan efisien melalui mengidentifikasi masalah, pengembangan strategi dan bahan 
instruksional, serta pengevaluasian terhadap strategi dan bahan instruksional untuk menentukan hal-hal yang direvisi (Nasrudin, 2020).

Pengembangan instruksional dan desain instruksional sama-sama, (1) memiliki tujuan akhir yang sama, yaitu menghasilkan satu set produk instruksional disebut sistem instruksional yang efektif dan efisien untuk mencapai tujuan pembelajaran; dan (2) melaksanakan proses yang dimulai dengan mengidentifikasi masalah, mengembangkan strategi dan bahan instruksional dan diakhiri dengan mengevaluasi efektivitas dan efisiensinya dengan kegiatan revisi (Atwi Suparman, h. 91). Jadi, proses pengembangan instruksional sendiri dimulai dengan mengidentifikasi masalah, dilanjutkan dengan mengembangkan strategi dan bahan instruksional, kemudian diakhiri dengan mengevaluasi efektivitas dan efisiensinya. yang meliputi kegiatan perancangan/ desain instruksional dirasakan berat oleh tutor/widyaiswara Pelatihan Jarak Jauh Online di BDK Jakarta. Desain instruksional menyediakan berbagai kegiatan pembelajaran termasuk di dalamnya konten bahan ajar, strategi, hingga penilaian. Pengembangan yang meliputi kegiatan perancangan/ desain instruksional dirasakan berat oleh tutor /widyaiswara Pelatihan Jarak Jauh Online di BDK Jakarta. Desain instruksional menyediakan berbagai kegiatan pembelajaran termasuk di dalamnya konten bahan ajar, strategi, hingga penilaian. Masih rendahnya kemampuan tutor untuk menyusun desain instruksional juga menjadi permasalahan di BDK, sehingga jenis diklat online kurang banyak keragamannya. Bagi yang sudah mengikuti semua jenis DJJ online di BDK Jakarta, menjadi kesulitan memilih jenis diklat disebabkan kurang berkembangnya jenis diklat online yang baru. Widyaiswara BDK Jakarta harus mengembangkan desain-desain instruksional untuk jenis diklat online yang baru. Hal ini sebagaimana yang dikemukakan Helmansyah dan Prawira bahwa perlu pembelajaran online karena memiliki beberapa keunggulan (Helmansyah et al., 2021).

Dalam rangka mengatasi kesulitan tutor/ widyaiswara dalam pengembangan desain instruksional DJJ online di BDK Jakarta, maka Penulis memberikan alternatif solusi melakukan standarisasi pengembangan desain instruksional DJJ online di BDK Jakarta melalui Bimbingan Teknis (Bimtek) pengembangan desain instruksional berbagai jenis DJJ online oleh tutor/ widyaiswara BDK Jakarta. Tujuan dari kegiatan standarisasi pengembangan desain instruksional ini adalah sebagai kontribusi konsep pemikiran dalam bentuk pengkonsultasian pada Balai Diklat Keagamaan (BDK) Jakarta, khususnya aspek pengembangan desain instruksional Diklat Jarak Jauh (DJJ) online untuk jenis diklat baru serta untuk menumbuhkan kreatifitas di kalangan Widyaiswara, sehingga mampu berkontribusi bagi kemajuan Diklat Jarak Jauh (DJJ) online di BDK Jakarta. Selain itu tujuan penulisan ini adalah menumbuhkan kreatifitas di kalangan Widyaiswara, sehingga mampu berkontribusi bagi kemajuan penyelenggaraan DJJ online di BDK Jakarta. Konsep perkonsultansian diharapkan menjadi wahana transformasi pengembangan desain instruksional DJJ online dimasa akan datang.

\section{METODOLOGI}

Artikel ini didasari atas penelitian yang telah dilaksanakan dengan menggunakan pendekatan kualitatif, dengan metode analisis deskritif. Karena itu, dalam artikel data yang disajikan dianalisis secara analisis deskriptif. Pendekatan dan metode penelitian ini sebagaimana yang dikemukakan Sugiarto dalam Prawira (Prawira \& Kurnia, 2020). Sementara itu, sumber data yang peneliti kaji bersumber dari sejumlah Pelatihan yang dilaksanakan di Balai Diklat Keagamaan Jakarta antara tahun 2019-2020.

Langkah pertama yang dilaksanakan dalam penelitian ini adalah Menyusun rancangan program kegiatan. Selanjutnya dianalisis secara deskriptif dengan disertai data pendukung lainnya. Data pendukung ini didapatkan dari Bagian Perencanaan Balai Diklat Keagamaan Jakarta. Salah satu bentuk analisis dalam sebuah penelitian adalah analisis. Analisis situasi ini sejalan dengan pendapat bahwa (Mulasari, Husodo, \& Muhadjir, 2016).Analisis terhadap kondisi pelaksanaan diklat online ini bertujuan untuk mengumpulkan informasi mencakup jenis dan bentuk kegiatan, pihak atau publik yang terlibat, tindakan dan strategi yang akan diambil, taktik, serta anggaran biaya yang diperlukan dalam melaksanakan program.

Selanjutnya untuk pemecahan masalah dan pengambilan keputusan adalah permasalahan sebagaimana yang telah dikemukakan pada bagian pendahuluan. Untuk dapat melakukan hal tersebut, metode yang dipergunakan dalam rancangan pengkonsultasian adalah Urgency, Seriousness, dan Growth (USG)(Utari, Sultan, \& Tirtayasa, 2020). Indikator untuk mengukur instrument yang telah dirancang ini dengan menentukan tingkat urgensi, keseriusan, dan perkembangan isu dengan menentukan skala nilai $1-5$. Isu yang memiliki total skor tertinggi merupakan isu prioritas. 
Analisis situasi dapat diartikan menganalisis situasi yang menjadi permasalahan atau ruang lingkup yang menjadi tanggung jawab dan batas wewenang sebuah unit dalam sebuah organisasi.

Data yang diperoleh dari hasil analisis dan kajian tersebut kemudian dideskripsikan sesuai dengan permasalahan yang terdapat dalam artikel ini. Barulah kemudian peneliti menafsirkan data yang telah dianalisis tersebut, dengan pendekatan analisis deskriptif. Selanjutnya, barulah peneliti menyimpulkan hasil kajian tersebut, apakah sesuai dengan rumusan masalah yang telah dikemukakan sebekumnya, atau malah sebaliknya.

\section{HASIL DAN PEMBAHASAN}

Berikut adalah temuan dari hasil analisis yang dilakukan oleh peneliti dengan menngunakan analisis metode USG yang dilaksanakan pada perkonsultansian ini dapat dilihat pada Tabel 2.

Tabel 2. Hasil metode USG (koleksi pribadi)

\begin{tabular}{cllllc}
\hline No & \multicolumn{1}{c}{ Masalah } & $U$ & $S$ & $G$ & Total \\
\hline 1 & $\begin{array}{l}\text { Masih rendahnya kemampuan widyaiswara dan } \\
\text { staf pegawai dalam melakukan pengembangan } \\
\text { desain instruksional Diklat Jarak Jauh Online }\end{array}$ & 5 & 5 & 5 & 15 \\
\hline 2 & $\begin{array}{l}\text { Kurang memadainya bandwith untuk } \\
\text { penyelenggaraan Diklat Jarak Jauh Online terkait }\end{array}$ & 4 & 4 & 4 & 12 \\
\hline 3 & $\begin{array}{l}\text { Masih rendahnya kemampuan widyaiswara dan } \\
\text { staf pegawai dalam pengembangan inovasi media } \\
\text { pada DJJ }\end{array}$ & 5 & 5 & 4 & 14 \\
\hline
\end{tabular}

Keterangan : berdasarkan skala likert 1-5 (5=sangat besar, 4=besar, 3=sedang, 2=kecil, 1=sangat kecil)

Atas dasar matrik tersebut maka isu yang merupakan prioritas adalah isu: masih rendahnya kemampuan widyaiswara dan staf pegawai dalam pengembangan desain instruksional Diklat Jarak Jauh Online.

Setelah diperoleh hasil metode USG tersebut, Penulis mengumpulkan informasi mengenai DJJ online dalam hal pengembangan desain instruksional melalui pengamatan, wawancara, dan diskusi dengan Kepala BDK Jakarta, Kepala Seksi Diklat Teknis dan widyaiswara. Penulis memberikan laporan kepada Kepala Balai Diklat Keagamaan Jakarta tentang permasalahan yang ditemukan dan meminta arahan untuk tindak lanjut dalam mewujudkan kegiatan yang diusulkan dalam proposal kegiatan(Utari et al., 2020). Pimpinan BDK Jakarta menghendaki adanya jenis-jenis diklat baru pada DJJ online, untuk itu setiap tutor/widyaiswara diberi tugas mengembangkan sebuah diklat baru. Namun pada pelaksanaannya, widyaiswara mengalami kesulitan dalam membuat desain instruksional Diklat online, sehingga hanya sebagian kecil yang terlaksana. Hal ini disebabkan masih kurangnya kompetensi widyaiswara/tutor dan staf pegawai dalam mendesain sebuah diklat.

Selanjutnya dilakukan koordinasi dengan penyelenggara Diklat Teknis di BDK Jakarta yaitu kepala seksi diklat tenaga teknis pendidikan dan keagamaan, kasubag Tata Usaha dan perencana BDK Jakarta. Koordinasi ini dilakukan untuk mencari kesamaan persepsi tentang permasalahan tentang DJJ online BDK Jakarta dan strategi penyelesaiannya. Diskusi bertujuan untuk menentukan bentuk dan waktu kegiatan, bahan beserta narasumber yang diperlukan, termasuk pembiayaannya. Selanjutnya Penulis melakukan sosialisasi kepada widyaiswara yang akan dilibatkan dalam kegiatan yang akan dilakukan dan mengharapkan agar semua elemen siap untuk menyukseskan kegiatan yang telah direncanakan. Kemudian dilakukan Analisis Kebutuhan Diklat tentang jenis diklat baru yang dibutuhkan. Setelah ditemukan kebutuhan diklat dari pengguna jasa diklat di BDK Jakarta, Penulis melakukan diskusi kepada widyaiswara tentang jenis diklat online baru yang akan didesain dan menentukan widyaiswara penyusun desain instruksionalnya. Penulis kemudian melakukan Bimbingan Teknis (Bimtek) tentang pengembangan desain instruksional kepada widyaiswara BDK Jakarta dan selanjutnya widyaiswara mengembangkan berbagai jenis desain instruksional DJJ online.

Bimbingan Teknis ini dilakukan untuk standarisasi pengembangan desain instruksional DJJ online di BDK Jakarta. Pada Bimtek ini tutor/widyaiswara diberi bimbingan baik klasikal maupun individual untuk pengembangan desain instruksional jenis diklat online baru di BDK Jakarta. Pengembangan desain instruksional diawali dengan mengidentifikasi kebutuhan peserta, kemudian menentukan tujuan instruksional, pemilahan bahan ajar yang telah tersedia (pdf, ppt, dII) dan 
menempatkannya dalam skenario pembelajaran. Selain itu juga harus dirancang aktivitas-aktivitas pembelajaran, seperti forum diskusi dan tugas untuk menambah pemahaman peserta terhadap suatu materi. Pada GBPP dituliskan Kompetensi Dasar, Pokok Bahasan, Sub Pokok Bahasan, Indikator Hasil Belajar, Kegiatan Belajar, Media dan Sumber Belajar, Strategi Evaluasi. Pada Satuan Acara Pembelajaran dirancang Pokok Bahasan tiap Kegiatan Belajar, Sub Pokok Bahasan, Kegiatan belajar asynchronous dan synchronous. Media dan sumber belajar, Strategi Evaluasi. Setelah desain instruksional selesai disusun oleh masing-masing widyaiswara, langkah berikutnya dilakukan validasi terhadap desain instruksional tersebut. Validasi dilakukan oleh teman sejawat (widyaiswara) melalui diskusi . Selain itu juga dilakukan validasi dengan melakukan presentasi di depan pimpinan BDK Jakarta dan pakar desain instruksional.

Pada studi pendahuluan, gambaran secara menyeluruh mengenai pelaksanaan Diklat Jarak Jauh online pada tahuntahun sebelumnya (2013-2019) diperoleh dari hasil wawancara dengan kepala seksi, tutor/widyaiswara, dan peserta diklat jarak jauh tahun 2013-2019, studi dokumen (kurikulum yang digunakan pada diklat jarak jauh tahun 2013-2019 termasuk silabus, dan hasil kuesioner analisis kebutuhan diklat peserta diklat jarak jauh tahun 2013-2019. Berdasarkan wawancara dengan tutor dan alumni peserta diklat jarak jauh, studi dokumen, dan pengisian kuesioner analisis kebutuhan diklat, diperoleh informasi bahwa jenis diklat online di BDK Jakarta masih kurang, belum memenuhi kebutuhan stakeholder. Perkembangan jenis diklat pada tiap tahunnya juga sangat sedikit, sehingga alumni diklat online membutuhkan jenis diklat online yang baru.

Setelah dilakukan perkonsultansian, dihasilkan desain instruksional baru yang dikembangkan yaitu desain: Diklat guru Pendidikan Agama Islam SD, Diklat Bimbingan Konseling Diklat Publikasi Ilmiah, Diklat Manajemen Berbasis Madrasah, Diklat PKG dan PKB, Diklat Penelitian Tindakan Kepengawasan, dan Diklat Moderasi Beragama. Berdasarkan penilaian pakar dalam bidang desain pembelajaran, dapat disimpulkan bahwa semua desain pembelajaran online ini dikategorikan "baik"(Utari et al., 2020).

Proses pengembangan desain instruksional yang dilakukan telah menghasilkan desain, materi, dan media pembelajaran online untuk diklat guru Pendidikan Agama Islam SD, Diklat Bimbingan Konseling Diklat Publikasi IImiah, Diklat Manajemen Berbasis Madrasah, Diklat PKG dan PKB, Diklat Penelitian Tindakan Kepengawasan, dan Diklat Moderasi Beragama. Desain instruksional diawali dengan perumusan tujuan pembelajaran untuk diklat yang disusun berdasarkan hasil analisis kebutuhan diklat. Selain itu strategi pembelajaran online dengan menggunakan model William Horton telah dirancang pada silabus dan SAP (Satuan Acara Pembelajaran) diklat online. Aktivitas pembelajaran merujuk pada model William Horton, yang terdiri dari aktivitas menyerap materi (absorb activity), aktivitas melakukan (do activity), dan aktivitas menghubungkan (connect activity) dalam kegiatan tugas, agar peserta dapat menghubungkan antara materi yang dipelajari dengan tugas sehari-hari dalam melakukan penilaian kepada peserta didik. Pada pengembangan materi pembelajaran online, bahan ajar yang dikembangkan yaitu modul yang dikemas dalam format PDF, juga slide presentasi, dan video. Dalam pengembangan desain ini telah dilakukan validasi draft awal oleh teman sejawat, pakar desain pembelajaran, dan pimpinan. Pakar desain instruksional nilai yang dikategorikan "baik".

\section{SIMPULAN}

Berdasarkan data yang diperoleh dari hasil analisis serta pembahasan, maka beberapa simpulan yang dapat dikemukakan sebagai berikut: Pengembangan desain instruksional DJJ online di BDK Jakarta untuk beberapa jenis DJJ baru dapat dilakukan melalui perkonsultansian. Desain instruksional jenis DJJ baru di BDK Jakarta telah divalidasi melalui diskusi dengan teman sejawat.

\section{PUSTAKA ACUAN}

Gustafson, Kent L. dan Robert Meribel Branch. (2002) Survey of Instructional Development Models Fourth Edition. New York: Eric.

Helmansyah, H., Prawira, Y. A., \& Nugraha, F. (2021). CONSIDERING ONLINE TRAINING: RESPONSE AND EXPECTATION IN THE PANDEMIC COVID-19, Jurnal Perspektif, 14(1), 161-179. Retrieved from https://perspektif.bdkpalembang.id/index.php/perspektif/article/view/22.

Ko \& Rossen. (2008). Teaching Online: A Practical Guide. New York: Routledge.

Kurnia, T., \& Prawira, Y. A. (2020). PEMENUHAN ASPEK AFEKTIF SISWA SD DALAM PEMBELAJARAN JARAK JAUH MELALUI KOMITMEN BELAJAR PADA MASA PANDEMI COVID-19. JPDI STKIP Singkawang, 5(2), 40 
44.

Mulasari, A., Husodo, A. H., \& Muhadjir, N. (2016). Jurnal Kesehatan Masyarakat A SITUATION ANALYSIS OF WASTE PROBLEM IN YOGYAKARTA, 11(2).

Nasrudin, A. (2020). THE INFLUENCE OF LEADERSHIP ON MOTIVATION AND EMPLOYEE S ' PERFORMANCE, Tatar Pasundan: Jurnal Diklat Keagamaan, XIV, 50-64.

Nugraha, F. (2020). Pendidikan dan Pelatihan: Konsep dan Implementasi dalam Pengembangan Sumberdaya Manusia. Jakarta: LDPress.

Peraturan Menteri Agama Republik Indonesia Nomor 4 Tahun 2012 tentang Penyelenggaraan Pendidikan dan Pelatihan Teknis di Lingkungan Kementerian Agama Pasal 2

Prawira, Y. A., \& Kurnia, T. (2020). STAND UP COMEDY : LANGUAGE PRESERVATION ON BAHASA INDONESIA STAND UP COMEDY SEBAGAI UPAYA PEMERTAHANAN BAHASA INDONESIA, Tatar Pasundan: Jurnal Diklat Keagamaan, XIV, 27-37.

Prawira, Y. A., \& Nugraha, F. (2021). Peningkatan Kompetensi Pedagogik Guru Madrasah Melalui Pelatihan Partisipatif Secara Daring Berbasis Heuristik, AKSARA, 7(2), 307-316.

Rachmawati, R. (2019). Pengawas sekolah/madrasah: pengembangan karir seorang pendidik. Tatar Pasundan : Jurnal Diklat Keagamaan, XIII, 84-92.

Restendi, D., Nugraha, F., \& Trianto, A. (2020). Pengembangan Sistem Pelatihan Jarak Jauh Berbasis Moodle di Balai Diklat Keagamaan Bandung. Andragogi: Jurnal Diklat Teknis Pendidikan dan Keagamaan, 8(2), 540-552.

Suparman, Atwi. (2012) Desain Instruksional Modern. Jakarta: Erlangga.

Utari, E., Sultan, U., \& Tirtayasa, A. (2020). ANALISIS MATRIKS USG (URGENCY, SERIOUSNESS AND GROWTH ) BANTEN MANGROVE CENTER BAGI MASYARAKAT KELURAHAN, 15(2). 